\title{
WAVE OVERTOPPING AND FLOOD RISK ASSESSMENT IN HARBOURS: A CASE STUDY OF THE PORT OF LAS NIEVES, GRAN CANARIA
}

\author{
JAVIER SANTANA-CEBALLOS ${ }^{1}$, CONCEICAO JUANA FORTES ${ }^{2}$, \\ MARIA TERESA REIS ${ }^{2}$ \& GERMÁN RODRÍGUEZ ${ }^{1,3}$ \\ ${ }^{1}$ Departamento de Física, Universidad de Las Palmas de Gran Canaria, Las Palmas de Gran Canaria, Spain \\ ${ }^{2}$ Laboratorio Nacional de Engenharia Civil (LNEC), Portugal \\ ${ }^{3}$ Applied Marine Physics and Remote Sensing Group, Institute of Environmental Studies and Natural Resources \\ (iUNAT), Universidad de Las Palmas de Gran Canaria, Las Palmas de Gran Canaria, Spain
}

\section{ABSTRACT}

This paper presents the analysis of the probability of occurrence of wave overtopping events as well as its consequences at the Port of Las Nieves in Agaete, Gran Canaria Island, with the evaluation of the resulting level of flood risk. The study has been conducted using a third-generation spectral wave model to reproduce wave propagation from deep to shallow water depths considering the associated mean sea level, and a neural network-based model, for estimating mean wave overtopping discharges. Results reveal that overtopping in the initial sections of the port, located in the port access area, is substantially higher than that associated with the cross-sections of the main body of the breakwater, so that control actions to reduce overtopping are required due to the important socioeconomic implications regarding the infrastructure inoperability.

Keywords: wave overtopping, flood risk, neural networks, Port of Las Nieves.

\section{INTRODUCTION}

Coastal harbours play a vital role as economic hubs in terms of trade, communications and tourism. The adequate development of port activities depends on the ability of the protecting structures for providing shelter and facilities to the users. In particular, coastal harbours must be able to offer operating conditions during most of the year and withstand extreme wave conditions, minimising economic risks as well as risks for humans, their properties, and the environment.

The performance of coastal and harbour structures is often measured in terms of the wave overtopping discharge behind it and, as a consequence, the safety limits are set at specific overtopping discharges, defining the allowable rate under operating and design conditions. Accordingly, frequency, pattern and severity of wave overtopping events have to be examined to determine critical locations along the structure, to define proper control measures and to minimize flooding of the infrastructure as much as possible, to attain the expected standard of performance.

Consequently, wave overtopping is one of the most important phenomena concerning both the functional efficiency and the structural safety of coastal and port structures, such as breakwaters. However, wave overtopping is a very complex phenomenon influenced by a large number of factors, in addition to the inherent random nature of wind-generated waves impacting against the coastal structures. Thus, overtopping is affected by processes governing the mean sea level over which wave trains propagate and by the sea bottom geomorphology, as well as by the characteristics of the defence structure. Due to its complexity, wave overtopping has been studied from different perspectives and using various methods for estimating the wave overtopping rate at distinct structures.

The most-widely used tools for predicting wave overtopping of coastal and harbour structures are empirical/semi-empirical formulae based on physical model tests (e.g. Owen 
[1], Besley [2], Reis et al. [3], EurOtop [4]). However, direct application of these formulae is limited to simple structural configurations and to specific wave/water-level conditions.

Physical model tests remain the most reliable method for determining overtopping. They are used for prototype studies, as well as providing data for the development, calibration and validation of other prediction methods. Results from field measurements or from large-scale laboratory tests are still rather rare (Franco et al. [5], Geeraerts \& Boone [6], Hordijk [7], Pullen \& Allsop [8], Carrasco et al. [9]). Most studies have been performed under the CLASH European project in order to fill this gap and allow investigation of both the model and scale effects (Kortenhaus et al. [10], De Rouck et al. [11]).

In recent years, due to the continuous increase in computer power, numerical models of wave overtopping have been developed further and their use is becoming increasingly attractive (Hu et al. [12], Losada et al. [13], Didier et al. [14]). They are more flexible than both formulae and physical models; and the more complex models, once calibrated and validated, can be configured and applied reliably to a large range of alternative geometries and wave conditions. However, their use in practical engineering applications still has limitations, related to computational cost and to their own limitations. For flood warning purposes, where the computation of many wave overtopping scenarios is needed, models that solve the NLSW equations (Hu et al. [12], Reis et al. [15], Zijlema et al. [16]) have been used due to their low computational cost. Nowadays, new forecast models suggest the implementation of more complex models, namely VOF models (Zou et al. [17]).

The use of artificial neural networks is also proving to be a way forward (Medina et al. [18], Wedge et al. [19], Coeveld et al. [20], Verhaeghe [21]). The objective of this paper is to evaluate the wave overtopping rate and its flooding consequences in terms of risk in the Port of Las Nieves (Agaete, Gran Canaria). The evaluation is based on a methodology which uses a neural network-tool to calculate mean overtopping discharges (Reis et al. [22], Poseiro et al. [23], Fortes et al. [24]), taking into account the sea state conditions (waves and water levels) reaching the structure.

\section{STUDY AREA}

Las Nieves Port, also known as Puerto de Agaete, is located in Agaete, a town at the northwest coast of Gran Canaria Island, in the Canary Archipelago, Spain (Fig. 1(a)). It is a coastal infrastructure managed by the Canary government with large socioeconomic and cultural importance, mainly due to its role in fishing and transport activities, but also by its role as a coastal defence structure, protecting its two inner beaches and the buildings located at its back (see Fig. 1(b)). Therefore, its inoperability has serious socioeconomic drawbacks.

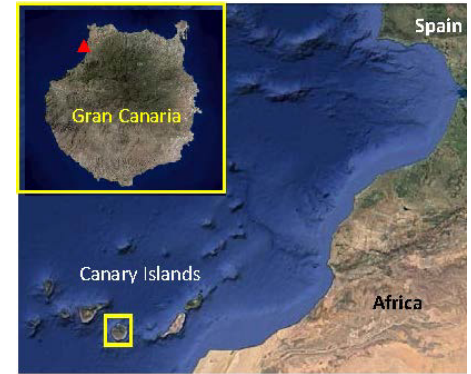

(a)

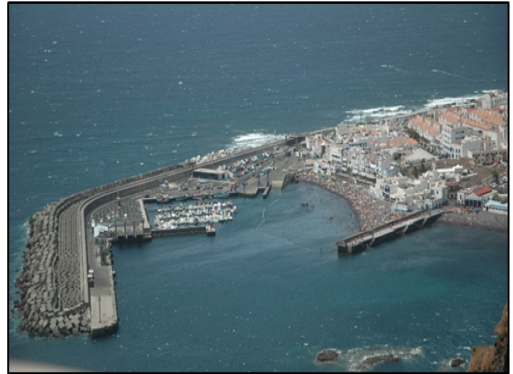

(b)

Figure 1: (a) Location of the study area in Canary Islands; (b) Aerial view of the Port of Las Nieves in Agaete, Gran Canaria Island. 


\section{DATA AND METHODOLOGY}

The experimental databases, including waves, tides and bathymetry conditions, as well as the approaches used to assess wave overtopping and flooding risk, are briefly described in the following subsections.

\subsection{Datasets}

Offshore wave climate has been characterised by considering the significant wave height, peak period, and mean wave direction associated to every sea state recorded, by using a directional wave buoy, during the period from 2003 to 2013. This dataset has been complemented and enlarged with the characteristic wave parameters resulting from hindcasting (1958-2001, set of SIMAR-44 database) [25], and predictions (1995-2015, set of WANA database) [25], at two points (1017013 SIMAR-44 point and 1016012 WANA point) and located close to the study zone, as depicted in Fig. 2. Due to the small fetch - less than $20 \mathrm{~km}$ - between the points where information is available and the port being studied, the generation of wind waves between both zones was not considered.

Sea level data have been obtained from two tide gauges installed by Puertos del Estado [26], [27] in the port of Las Palmas for successive periods of time, 1992-2009 and 20092015. Due to the proximity between Las Palmas and Agaete, and the characteristics of the tidal wave, it is acceptable to admit that the records obtained at Las Palmas are representative of the sea level behaviour in the area of study. The tide on the island is semi-diurnal, with two high tides and two low tides slightly different each day.

Bathymetric information near the port has been provided by Canary Islands Ports and obtained by the Spanish Ministry of Environment [28]. This information does not include the location of the wave buoy and hindcasting/prediction points. So, it has been complemented with a deep water bathymetry provided by the British Oceanographic Data Centre, BODC [29] (Fig. 2).

\subsection{Wave propagation}

The SWAN model 40.72a [30] has been used for modelling the transformation of offshore wave conditions during their propagation towards the coastal zone of interest. The directional spectrum has been characterized with a JONSWAP model, considering 30 frequency intervals between 0.02 and $0.3 \mathrm{~Hz}$ and a directional discretization of $2^{\circ}$.

\subsection{Definition of study sections}

Any change in the section type of the infrastructure imply differences in the overtopping probability of occurrence while variations in its use entails differences in the consequences of the flood. With this in mind, the infrastructure has been divided into sections according to their structural typology and the use given to the protected areas.

Wave overtopping in the port has been evaluated in seven sections located along the structure. The structure itself has been divided into two sub-sections: "E.1 Avenue sections" (access to the port), comprising sections E1 to E3; and "E.2. Dyke Sections", which encompasses the remaining sections, E4 to E7 (see Fig. 3).

\subsection{Overtopping and flood risk evaluation}

The methodology used for the assessment of flood risk by wave overtopping is presented in the following two subsections. 


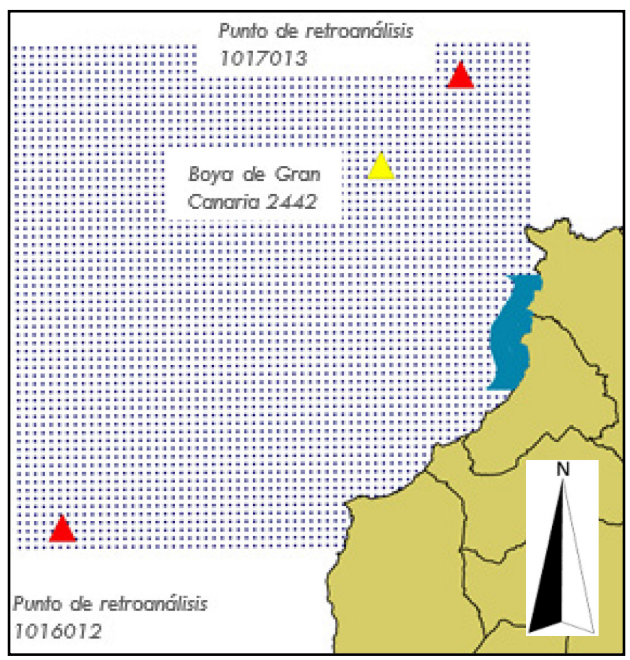

Figure 2: Location of wave buoy (in yellow), hindcasting/prediction points (in red) and grid points of used bathymetries (blue dots, provided by BOCD [2]).

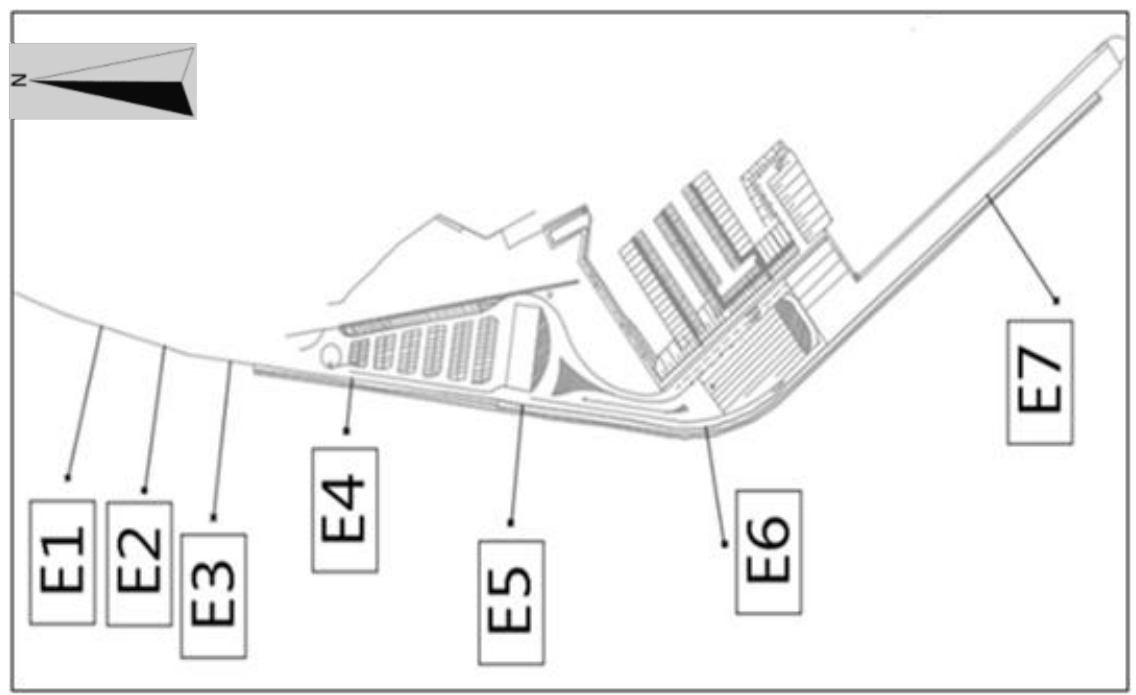

Figure 3: Sections along Port of Las Nieves.

\subsubsection{Wave overtopping}

Wave overtopping evaluation has been performed by means of the artificial neuronal network (ANN) tool NN_OVERTOPPING2, developed in the context of the European project CLASH [20]. This tool is built on a database of about 8,400 test conditions, which originate from many different international laboratories. It employs measurements from physical model tests covering a wide range of coastal structure types (such as dikes, rubble mound breakwaters and caisson structures) and different wave conditions (van der Meer et al. [31]). 
This variability is imposed by the input parameters that produce Froude scaled mean wave overtopping discharges and the associated confidence intervals. In addition, prototype mean overtopping estimates, allowing for scale and model effects, are provided. Nevertheless, Coeveld et al. [20] suggest that the reliability of the predictions should be verified using dedicated physical model tests for the particular wave conditions and structure geometry under consideration.

\subsubsection{Flood risk}

The overtopping threshold values used in this work are based on the recommendations of Pullen et al. [32], who set limit values for mean overtopping discharge according to the type of structure and its uses for people, vehicles, boats, etc.

The flood risk is evaluated qualitatively by combining the probability of occurrence of mean overtopping discharges above a given threshold and the consequences of such threshold being surpassed. For simplicity, probability and consequences scales are assigned to the probability of occurrence and to the consequences, respectively, instead of using the probability of occurrence of the event and the damage associated with it. The risk, $R$, is then given by

$$
R=P \cdot C
$$

where $P$ is the probability level and $C$ represents the consequences level. Thus, the process of qualitative evaluation of the flooding risk by overtopping is carried out by using the methodology proposed by Santos et al. [33] (and used in Neves et al. [34], [35], Silva et al. [36], Reis et al. [22], Rocha et al. [37], Poseiro et al. [23], [38]).

This methodology, allows carrying out a qualitative assessment of overtopping risk, using the risk level concept, by applying the following five-step procedure:

- Definition of acceptable thresholds for mean overtopping values with the guidance of Pullen et al. [32] according to structures characteristics and use;

- Establishment of the probability level for the different overtopping thresholds considering a linear scale of five levels of probability (from "Unlikely" to "Frequent"): 1) Unlikely, less than $1 \%$; 2) Unusual, 1-10\%; 3) Occasional, 10-25\%; 4) Probable, 25-50\%; and 5) Frequent, more than 50\%;

- Selection of the consequences level for each threshold, based upon the recommendations by Pullen et al. [32], site characteristics and information obtained from the responsible authorities, with five levels of consequences (from "Insignificant" to "Catastrophic"): Insignificant - 1; Limited - 2; Serious - 5; Very Serious - 10; and Catastrophic - 25;

- Computation of the risk level associated with the different pre-set thresholds, considering four levels of risk, $R$ (from "Insignificant" to "Unacceptable"): 1) Insignificant $(R=1-3)$; 2) Limited $(R=4-10)$; 3) Undesirable $(R=15-30)$; and 4) Unacceptable $(R=40-125)$;

- $\quad$ Production of risk level maps and analysis of risk level acceptability.

\section{RESULTS}

It has to be mentioned that some sea states could not be considered for sections E1, E2, and E3, with a natural volcanic platform seaward of the structural section, due to limitations of the neural network tool. This limitation can be partially eliminated by using a more detailed wave propagation model that includes propagation on the shallow natural volcanic platform. 
Furthermore, the breakwater has an unusual structural section, including a stilling basin, something that was not considered in the development of the neural network tool.

The probability (in percentage) of conditions in which the threshold values established for each cross-section are exceeded and the corresponding probability level are presented in Table 1, where cells corresponding to sections without a given use were marked with a script (-). Note that overtopping thresholds used in the present work have been established mainly based on the recommendations given by Pullen et al. [32]. The levels of consequences associated with flooding are given in Table 2 while Table 3 shows the flood risk levels, resulting from the product of the level of probability by the level of consequences.

As shown in Table 1, the thresholds that are more likely to be exceeded are those established for areas where pedestrians are present. This is particularly true for sections located in the port access. The exceedance probability reduces significantly for the sections forming integral part of the protection structure.

Regarding the presence of vehicles, the probability of threshold exceedance is null for all the sections. Furthermore, concerning the existence of buildings and boats, the probability of exceeding the corresponding thresholds is null along all the structure. In relation to the equipment use, it is observed that there are two sections (E4, E7) with unlikely level.

Table 1: $\quad$ Probability (\%) of exceeding the overtopping thresholds and corresponding probability levels.

\begin{tabular}{|l|c|c|c|c|c|c|c|c|c|c|}
\cline { 2 - 13 } \multicolumn{1}{c|}{} & \multicolumn{2}{c|}{ Pedestrians } & \multicolumn{2}{c|}{ Vehicles } & \multicolumn{2}{c|}{ Equipment } & \multicolumn{2}{c|}{ Buildings } & \multicolumn{2}{c|}{ Boats } \\
\hline Section & $\%$ & Level & $\%$ & Level & $\%$ & Level & $\%$ & Level & $\%$ & Level \\
\hline E1 & 2.00 & $(2)$ & 0 & $(1)$ & - & - & - & - & - & - \\
\hline E2 & 2.55 & $(2)$ & 0 & $(1)$ & - & - & 0 & $(1)$ & - & - \\
\hline E3 & 2.57 & $(2)$ & 0 & $(1)$ & - & - & 0 & $(1)$ & - & - \\
\hline E4 & 0.70 & $(1)$ & 0 & $(1)$ & 0.14 & $(1)$ & 0 & $(1)$ & - & - \\
\hline E5 & 0.44 & $(1)$ & 0 & $(1)$ & - & - & 0 & $(1)$ & 0 & $(1)$ \\
\hline E6 & 0.37 & $(1)$ & 0 & $(1)$ & - & - & - & - & 0 & $(1)$ \\
\hline E7 & 0.41 & $(1)$ & 0 & $(1)$ & 0.33 & $(1)$ & - & - & 0 & $(1)$ \\
\hline
\end{tabular}

Table 2: Associated consequences for pedestrians (P), environment (Env), port management (PM), buildings (B), equipment (Eq), structure (S) and vehicles (V).

\begin{tabular}{|l|c|c|c|c|c|c|c|}
\hline Section & P & Env & PM & B & Eq & S & V \\
\hline E1 & S (5) & I (1) & VS (10) & I (1) & - & L (2) & L (2) \\
\hline E2 & S (5) & I (1) & VS (10) & L (2) & - & L (2) & L (2) \\
\hline E3 & S (5) & I (1) & VS (10) & L (2) & - & L (2) & L (2) \\
\hline E4 & S (5) & L (2) & L (2) & S (5) & S (5) & L (2) & S (5) \\
\hline E5 & S (5) & L (2) & L (2) & S (5) & S (5) & L (2) & S (5) \\
\hline E6 & S (5) & L (2) & L (2) & L (2) & - & L (2) & S (5) \\
\hline E7 & S (5) & L (2) & S (5) & - & VS (10) & L (2) & S (5) \\
\hline
\end{tabular}


Table 3: Levels of risk (R) obtained as the product of the highest probability level per section $(\mathrm{P})$ and the highest consequences level per section (C).

\begin{tabular}{|l|c|c|c|c|l|}
\hline Section & $\mathrm{P}$ & $\mathrm{C}$ & \multicolumn{2}{|c|}{$\mathrm{R}$} & Risk control \\
\hline E1 & 2 & 10 & 20 & Undesirable & $\begin{array}{l}\text { Consider the possibility of risk elimination. } \\
\text { Monitoring is essential. }\end{array}$ \\
\hline E2 & 2 & 10 & 20 & Undesirable & $\begin{array}{l}\text { Consider the possibility of risk elimination. } \\
\text { Monitoring is essential. }\end{array}$ \\
\hline E3 & 2 & 10 & 20 & Undesirable & $\begin{array}{l}\text { Consider the possibility of risk elimination. } \\
\text { Monitoring is essential. }\end{array}$ \\
\hline E4 & 1 & 5 & 5 & Limited & Some control actions are necessary. \\
\hline E5 & 1 & 5 & 5 & Limited & Some control actions are necessary. \\
\hline E6 & 1 & 5 & 5 & Limited & Some control actions are necessary. \\
\hline E7 & 1 & 10 & 10 & Limited & Some control actions are necessary. \\
\hline
\end{tabular}

Consequences associated with overtopping of the structure (Table 2) are serious in all the sections regarding the presence of pedestrians. However, environmental consequences of wave overtopping events are insignificant in the sections of the Port access (E1, E2, E3) and limited in the rest. Port management is very seriously hampered if overtopping affects to port access sections and seriously hampered if flooding exists in the areas designated for passenger's transport activity (E7). Concerning buildings, overtopping consequences vary among insignificant, limited and serious according to the building use (private properties, entrance checkpoint and port terminal). If overtopping affects lifting equipment, consequences are catalogued as serious (E4, E5) and has very serious implications if it affects to passenger's gangway (E7). Overtopping affection to the structure is limited along the entire infrastructure.

Based on the above results, the estimated risk level for the different sections of the structure (Table 3) is classified as "Undesirable" in the sections corresponding to the port access road and as "Limited" in the remaining zones. However, among those sections classified with "Limited" risk, the final section of the structure (E7) has associated a significantly higher risk value (10) than the remaining sections (5), because of the affection to passenger's gangway.

\section{CONCLUSIONS}

Wave overtopping probability of occurrence and the resulting flood risk at the Port of Las Nieves in Agaete, has been explored by using large databases of offshore wave climate and associated tidal conditions, as well as bathymetric characteristics. Nearshore wave conditions have been obtained by means of a third generation wave model, the SWAN model, while mean overtopping discharges have been evaluated using a neural network-based model, NN_OVERTOPPING2.

The frequency of occurrence of overtopping in the initial sections of the Port of Las Nieves (port access area) is substantially higher than that associated with the cross-sections located in the main body of the breakwater. These findings highlight the need to undertake actions against wave overtopping in the area of the access road to the Port of Las Nieves due to the significant socioeconomic implications regarding the infrastructure inoperability.

ACKNOWLEDGEMENTS

The financial support of the FCT project HIDRALERTA - Flood forecast and alert system in coastal and port areas, ref. PTDC/AAC-AMB/120702/2010, is gratefully acknowledged. 
The authors also thank Puertos del Estado (Spain) for providing wave and tide datasets as well as to Puertos Canarios for providing information regarding Port of Las Nieves structure and activities.

\section{REFERENCES}

[1] Owen, M.W., 1980. Design of seawalls allowing for wave overtopping. Report Ex, 924, 39.

[2] Besley, P., 1999. Overtopping of seawalls: design and assessment manual. Environment Agency. Bristol, R \& D Technical Report.

[3] Reis, M.T., Hedges, T.S., Neves, S., Neves, M.G., Hu, K. \& Mase, H., 2013. Extending the H\&R Wave Overtopping Model to Vertical Structures. In Proc. 6th SCACRInternational Short Course/Conference on Applied Coastal Research.

[4] EurOtop, 2016. Manual on wave overtopping of sea defences and related structures. An overtopping manual largely based on European research, but for worldwide application. Van der Meer, J.W., Allsop, N.W.H., Bruce, T., De Rouck, J., Kortenhaus, A., Pullen, T., Schüttrumpf, H., Troch, P. and Zanuttigh, B., www.overtoppingmanual.com

[5] Franco, L., Briganti, R. \& Bellotti, G., 2005. Ostia site report on full scale measurements (2nd full winter season). Modimar SRL: Rome, Italy.

[6] Geeraerts, J. \& Boone, C., 2004. Report on full scale measurements in Zeebrugge, 2nd full winter season. CLASH WP3 - Report. Ghent University: Belgium.

[7] Hordijk, D., 2004. Report on Field Measurements - Petten sea defence: Storm Season 2003-2004. CLASH WP3 - Report. Rijkswaterstaat: The Netherlands.

[8] Pullen, T. \& Allsop, N.W.H., 2004b. D33 Report on Full Scale Measurements Samphire Hoe, CLASH WP3 - Report. HR: Wallingford, UK.

[9] Carrasco, A.R., Reis, M.T., Neves, M.G., Ferreira, Ó., Matias, A. \& Almeida, S., 2014. Overtopping hazard on a rubble mound breakwater. Journal of Coastal Research, 70(sp1), 247-252.

[10] Kortenhaus, A. et al., 2005. CLASH: D40 Report on Conclusions of Scale Effects. CLASH WP7 - Report. LWI: Germany.

[11] De Rouck, J., Geeraerts, J., Troch, P., Kortenhaus, A., Pullen, T. \& Franco, L., 2005. New results on scale effects for wave overtopping at coastal structures. Proceedings of ICE Coastlines, Structures \& Breakwaters, 5, 29-43.

[12] Hu, K., Mingham, C.G. \& Causon, D.M., 2000. Numerical simulation of wave overtopping of coastal structures using the non-linear shallow water equations. Coastal Engineering, 41(4), 433-465.

[13] Losada, I.J., Lara, J.L., Guanche, R. \& Gonzalez-Ondina, J.M., 2008. Numerical analysis of wave overtopping of rubble mound breakwaters. Coastal Engineering, 55(1), 47-62.

[14] Didier, E., Neves, D., Teixeira, P. \& Neves, M.G., 2014. SPH numerical and physical modelling of wave overtopping over a porous breakwater. Proc. 3rd IAHR Europe Congress, April 14-16, 2014, Porto, Portugal.

[15] Reis, M.T., Neves, M.G., Lopes, M.R., Hu, K. \& Silva, L.G., 2011. Rehabilitation of Sines West Breakwater: wave overtopping study. In Proceedings of the Institution of Civil Engineers-Maritime Engineering, Vol. 164, No. 1, pp. 15-32, Thomas Telford Ltd.

[16] Zijlema, M., Stelling, G. \& Smit, P., 2011. SWASH: An operational public domain code for simulating wave fields and rapidly varied flows in coastal waters. Coastal Engineering, 58(10), 992-1012. 
[17] Zou, Q.P. et al. (2013). Ensemble prediction of coastal flood risk arising from overtopping by linking meteorological, ocean, coastal and surf zone models. Quarterly Journal of the Royal Meteorological Society, 139(671), 298-313.

[18] Medina, J., Gonzalez-Escriva, J., Garrido, J. \& De Rouck, J., 2003. Overtopping analysis using neural networks. In Proceedings 28th International Conference Coastal Engineering-Solving Coastal Conundrums, Vol. 2, pp. 2165-2177, World Scientific.

[19] Wedge, D.C., Ingram, D.M., Mingham, C.G., McLean, D.A., \& Bandar, Z.A., 2005. Neural network architectures and overtopping predictions. Maritime Engineering, 158(3): 123-133.

[20] Coeveld, E.M., Van Gent, M.R.A. \& Pozueta, B., 2005. Neural network: manual NN_Overtopping 2. CLASH WP8, WL-Delft Hydraulics: Delft, The Netherlands.

[21] Verhaeghe, H., 2005. Neural Network Prediction of Wave Overtopping at Coastal Structures. PhD Thesis, Universiteit Gent: Belgium.

[22] Reis, M.T. et al., 2011. Previsão dos galgamentos na baía da Praia da Vitória para avaliação de risco e alerta. In Proc. VI Congresso Planeamento e Gestão das Zonas Costeiras, Boa Vista: Cabo Verde.

[23] Poseiro, P., Fortes, C.J.E.M., Santos, J.A., Reis, M.T. \& Craveiro, J., 2013. Aplicação do processo de análise hierárquica (AHP) à análise das consequências de ocorrência de galgamentos. O caso da baía da Praia da Vitória". Proc. 8as Jornadas Portuguesas de Engenharia Costeira e Portuária, AIPCN/PIANC: Lisboa, 10.

[24] Fortes, C.J.E.M., et al., 2015. Ferramenta de apoio à gestão costeira e portuária: o sistema HIDRALERTA. Proc. VIII Congresso sobre Planeamento e Gestão das Zonas Costeiras dos Países de Expressão Portuguesa e $1^{a}$ Conferência Internacional "Turismo em Zonas Costeiras - Oportunidades e Desafios", Aveiro, 14 a 16 de outubro. ISBN: 978-989-8509-12-3.

[25] Puertos del Estado, 2008. Conjunto de datos SIMAR-44 (Proyecto HIPOCAS).

[26] Puertos del Estado. REDMAR red de mareógrafos de puertos del estado (Informe Anual 2009).

[27] Puertos del Estado. Resumen de parámetros relacionados con el nivel del mar y la marea que afectan a las condiciones de diseño y explotación portuaria (Puerto de Las Palmas). REDMAR. RED de MAReógrafos de Puertos del Estado. Informes Dirección Técnica.

[28] Ministerio de Medio Ambiente, 2005. Estudio ecocartográfico de la zona norte litoral de la isla de Gran Canaria.

[29] British Oceanographic Data Centre (BODC) www.bodc.ac.uk

[30] SWAN Team, 2011. "SWAN cycle III, version 40.85: Scientific and Technical Documentation." Delft University of Technology: Delft, The Netherlands.

[31] van der Meer, J.W., Verhaeghe, H. \& Steendam, G.J., 2009. The new wave overtopping database for coastal structures. Coastal Engineering, 56(2), 108-120.

[32] Pullen, T., Allsop, N.W.H., Bruce, T., Kortenhaus, A., Schutrumpf, H. \& Van Der Meer, J.W., 2007. EurOtop: Wave Overtopping of Sea Defences and Related Structures: Assessment Manual. 178p., Environment Agency, UK/Expertise Netwerk Waterkeren, NL/Kuratorium fur Forschung im Kusteningenieurwesen: Germany. ISBN 978-3-8042-1064-6.

[33] Santos, J.A. et al., 2011. Aplicação de uma metodologia para avaliação do risco para a navegação e galgamentos no Porto da Praia da Vitória. Proc. 7as Jornadas Portuguesas de Engenharia Costeira e Portuária, AIPCN/PIANC: Porto, 6. 
[34] Neves, D.R. et al., 2010. Avaliação do risco para a navegação em dois portos portugueses. In Proc. IV SEMENGO, Seminário e Workshop em Engenharia Oceânica, Vol. 3.

[35] Neves, D.R. et al., 2012. Metodologia de avaliação do risco associado ao galgamento de estruturas marítimas: Aplicação ao porto e à baía da Praia da Vitória, Açores, Portugal. Revista de Gestão Costeira Integrada, 12(3), 291-312.

[36] Silva, E., Santos, J.A. \& Reis, M.T., 2011. Porto da Praia da Vitória. Estimativa dos galgamentos da protecção marginal da baía. 7as Jornadas Portuguesas de Engenharia Costeira e Portuária.

[37] Rocha, T. et al., 2013. Avaliação comparativa do risco de galgamentos na Praia da Vitória, Terceira, Açores.

[38] Poseiro, P. et al., 2013, June. A methodology for overtopping risk assessment in port areas: Application to the Port of Praia da Vitória (Azores, Portugal). In Proc. 6th SCACR-International Short Course/Conference on Applied Coastal Research, Lisbon, pp. 4-7. 